Lisa Friederike Odparlik

\title{
Are agencies turning a blind eye to public access to environmental assessment information?
}

\section{Article, Postprint}

This version is available at https://doi.org/10.14279/depositonce-5944.

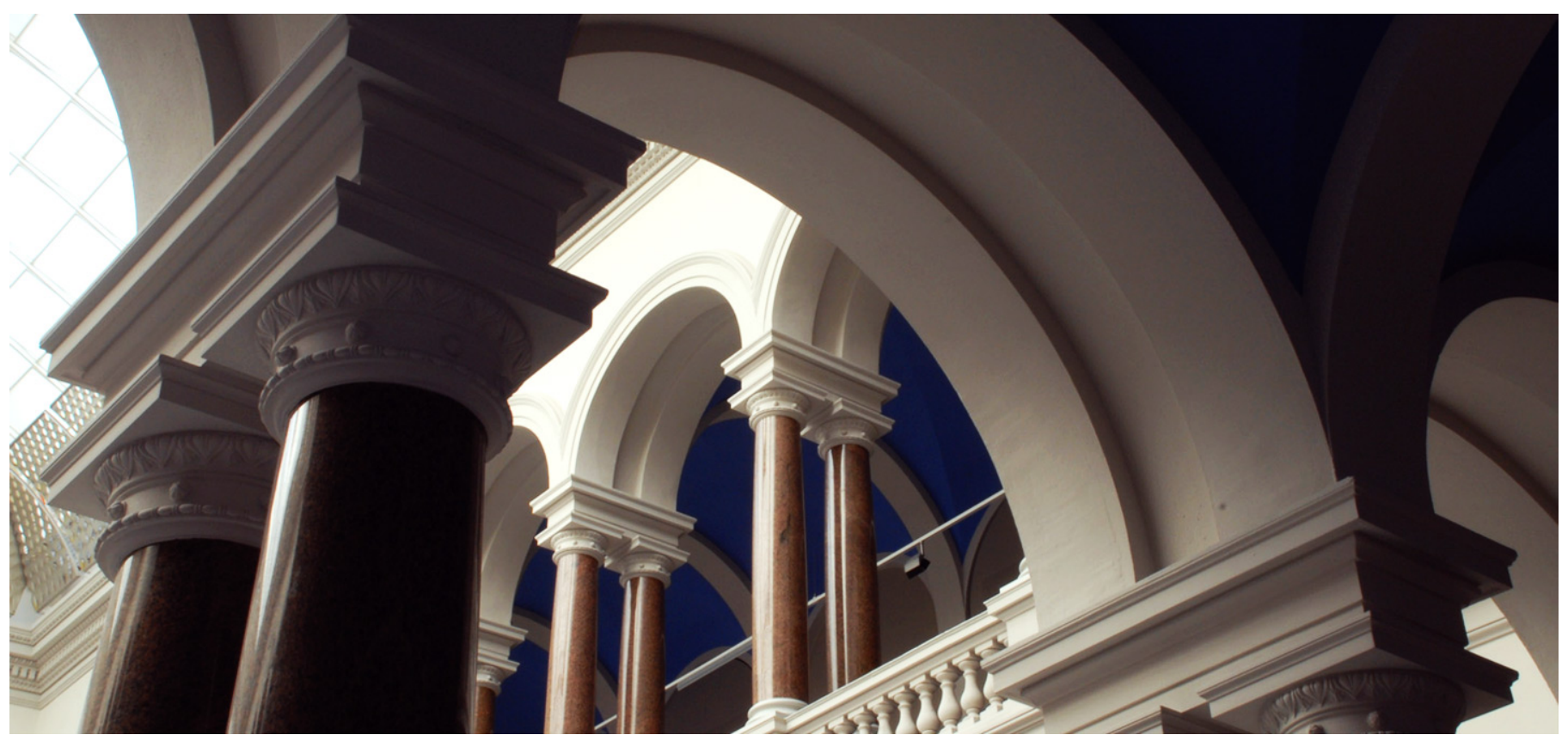

\section{Suggested Citation}

Odparlik, Lisa Friederike: Are agencies turning a blind eye to public access to environmental assessment information? - In: Journal of Environmental Assessment Policy and Management. - ISSN: 1757-5605 (online). - 17 (2015), 3. - 1550028. DOI: 10.1142/S1464333215500283. 


\title{
Are Agencies Turning a Blind Eye to Public Access to En- vironmental Assessment Information?
}

\author{
Lisa Friederike Odparlik
}

\begin{abstract}
For environmental assessments (strategic environmental assessment (SEA) and environmental impact assessment (EIA)) a wide range of data and documents is gathered, processed, and produced. In planning theory, this information is viewed to have a transformative function: It can affect perceptions in advance of a decision, thereby impacting the planning process at all levels and stages. The role of this information in supporting transparent public participation is often neglected. This paper analyses the current implementation of legal requirements providing access to information on environmental assessments (EAs) in Germany's electricity grid expansion and federal road planning sectors, using a criteria based case study analysis of agency websites. The 92 analysed websites primarily provide general planning information, technical information, and final decisions. One third of the websites provided EA documents, and show a clear need for improvement in information provision about and in support of public participation.
\end{abstract}

Keywords: Access to information; public participation; environmental assessment documents.

\section{Introduction}

For environmental assessments (EAs) (strategic EA (SEA); environmental impact assessments (EIA)) a wide range of data and documents is gathered, processed, and produced. In addition to the environmental impact study (EIS), further technical information, maps, transcripts of hearings, and comments build the basis for the approval decision of the competent planning authority. The role of this information in supporting a transparent process of public participation, a statutory element of the EA processes, is often neglected. Ideally, public participation should be viewed as a continuous, two-way communication process. In the first step the public $1^{11}$ is fully informed about the status and progress of studies and possible impacts of project, plan, program, and policy formulation and evaluation activities, which promotes full understanding of the processes and mechanisms of EA applied by the responsible agencies. In the second step all concerned citizens are invited to state their opinions and perceptions of objectives, needs, and preferences regarding resource use, alternative development, management strategies, further information needs, and assistance relative to the decision (Gauthier et al., 2011).

In planning theory, information is viewed to have a transformative function that can affect perceptions in advance of a decision, thereby impacting the planning process at all levels and stages (Hanna, 2000; Bartlett and Kurian, 1999). "Preparing and analysing data, interacting with nonagency players, and presenting information to the public can be transformative actions - even though their impact may not be explicit" (Hanna, 2000). Consequently, in support of consensus building among agency staff and the involved public, and especially to establish equal opportunities for informed decision-making, participation requires access to EA process information. Trans-

\footnotetext{
11 The term public was used without separation between public stakeholders and the general public, as the author argues that information should be available also beyond one single planning procedure, e.g. for comparison with similar projects.
} 
parent communication and access to process documents enable the public to understand potential impacts, differentiate various planning alternatives, and identify the potential consequences of their own preferences and objectives, thereby supporting a process of learning (Fischer, 2007; Jha-Thakur et al., 2009; Hourdequin et al., 2012). According to Kramer et al. (2011), the provision of comprehensive information ultimately leads to greater transparency and a greater ability to become involved. At the same time, information can become a limiting factor to effective participation (e.g. Hartley and Wood, 2005; Wiklund, 2011; Gauthier et al., 2011; Hourdequin et al., 2012). This may be the case if important background information on the process of EA is missing and the public does not know when or how to get involved (Wiklund, 2011; Wester and Mörn, 2013). Further, participation might be restricted if information is formally provided but the public is not aware of it, does not know how to access it, or the readability of reports is limited due to technical language and the public does not possess the expert knowledge to understand it (Hourdequin et al., 2012; Walker et al., 2014). Limited time to read, understand and prepare comments, illiteracy, and language barriers can further stand in the way of effective participation (Odparlik et al., 2012; Walker et al., 2014).

In the past years, international practice with its increasing use of web-based EA registries and agency or project specific websites to provide public access to information has shown promising approaches to overcome some of the barriers related to information provision in EA. Registries or websites inform when to participate and provide basic information about the planning process, legal aspects and other requirements. They allow access to relevant documents, e.g. screening and scoping documentation, impact studies, technical information and maps, transcripts of public hearings and submitted comments, planning decisions, as well as the continued availability of information and updates, e.g. on monitoring results. Internet-based access allows participants to inspect planning documents and submit their opinions at any time and location, regardless of official opening times and the physical availability of the planning documents (Schulze-Wolf and Köhler, 2008).

Legal provision has been shown to be a major driver in this development of web-based information provision (Odparlik and Köppel, 2013). With its amendments to the EIA directive, the European Union now also recognizes the fact that effective public participation needs information. As a result of the Aarhus Convention ${ }^{12}$ and Directive 2003/4/EC on public access to environmental information, EA information shall now be provided electronically via central portals of the EU Member States ${ }^{13}$ (Directive 2014/52/EU). As a European Member State, Germany is also affected by this change in the directive. Since 1990, when the first European Directive on EIA was incorporated into German national law with the Environmental Impact Assessment Act (UVPG ${ }^{14}$ ), projects with potentially harmful consequences have to undergo an EIA before approval is granted. Since 2004, plans and programs with potentially harmful environmental effects are also required to undergo a SEA. The EA itself represents an integral part of procedures applied by authorities when deciding upon approval of projects, plans, and programs (§2 (1) UVPG). While the German EIA today is considered to be an established instrument, literature still suggests that "substantial challenges to the further development of EIA, and to even stronger implementation of environmental

\footnotetext{
${ }^{12}$ Next to the right to participate in environmental decision-making and the access to litigation, the convention provides the right to receive environmental information that is held by public authorities (Hartley and Wood, 2005).

${ }^{13}$ EU Directive 2014/52/EU Article 6 paragraph 5: "Member States shall take the necessary measures to ensure that the relevant information is electronically accessible to the public, through at least a central portal or easily accessible points of access, at the appropriate administrative level."

14 The German abbreviations are used as official English abbreviations rarely exist for German laws.
} 
requirements in planning and decision-making practice [...] still exist" (Wende et al., 2012), which makes Germany an interesting case for analysis.

Inter alia, the German Environmental Impact Assessment Act (UVPG), the Freedom of Information Act (IFG), and the Environmental Information Act (UIG), which transforms the first column (access to information) of the Aarhus convention into national law, provide legal regulations for the access to environmental information relevant to the decision making process. The existence of these legal provisions notwithstanding, it is often criticized that a lack of transparency is an obstacle to effective participation. Examples such as the railway and urban development project Stuttgart $21^{15}$ and the non-transparent determination of flight paths at the airport Berlin-Brandenburg-International (BBI) ${ }^{16}$ showed that delayed (Köppel et al., 2012) or missing information and public involvement can lead to delays and tensions in the approval process.

Germany was chosen for further analysis based on the research hypothesis that a considerable gap between the conceptual legal requirement to provide information and the current implementation status of access to information on agency websites seems to exist. Drawing on a defined catalogue of best practice criteria, this paper analyses the provision of documents and information from the environmental assessment process for electricity grid expansion and federal road planning projects, two examples of EA in Germany's multi-governance planning system. While federal road planning, as part of federal transportation planning (including railways and waterways as well), is an old-timer in the field of planning (first national Transport Infrastructure Plan in 1973), electricity grid expansion planning, as a direct result from the publicly debated "Energiewende" (energy transition towards more renewable energies), can be viewed as the new kid on the block with high attention on a transparent planning process, which makes them an interesting pair for comparison.

\section{Legal regulations defining access to information}

Access to information in German planning and approval procedures is regulated in different laws. The German Freedom of Information Act (IFG) grants each person a legal right of access to official information from federal agencies, e.g. conventional documents, electronically stored information, drawings, graphics, diagrams and audio and video recordings. 11 of the 16 German states have adopted similar laws. A reason or justification is not required to bring a claim for information against federal agencies on the grounds of the Administrative Procedures Act (VwVfG), which regulates, for example, the planning procedure at the approval stage of an electricity grid or federal

\footnotetext{
15 The Stuttgart 21 project and especially the core of the project - a renewed central train station in Stuttgart — was the reason for heated debates on relative costs and benefits, geological stability and environmental concerns (protection of the cultural heritage of the existing train station and the adjacent Schloßgarten). Starting in 2007 several petitions and public demonstration lead to a ref- erendum in 2011 deciding whether the state of Baden-Württemberg should cease funding for the project. Even though the majority was in favor to continue with the project, following elections marked the Green Parties first majority in a German state, which is seen as a result of their opposition to the project and the hope for more direct democracy and transparent decision-making (Land- eszentrale für politische Bildung Baden-Württemberg n.d.).

16 In the case of the Berlin Brandenburg Airport the German air-traffic control announced a change of aircraft arrival and departure paths after permission was granted on grounds of different routes. These new flight paths significantly differ from earlier ones and caused a wave of protests and a lawsuit from citizens in areas in southern Berlin. Citizens argue that this misinformation took their right of participation as they could not know who would be affected and planning information was not accessible to them. While access to planning documents was provided after courts threatened with a fine, the lawsuit on grounds of an unlawful planning process was still rejected (Warner, 2011).
} 
road project (see Table 6). However, the act contains numerous exceptions by which the right may be restricted or denied completely. For instance, freedom of information only refers to completed processes, therefore no open access to ongoing planning procedures is permitted ( $§ 4$ IFG). The act further excludes personal data ( 55 IFG) and company related data ( 66 IFG).

In parallel, the German Environmental Information Act (UIG) transforms the first column (access to environmental information) of the Aarhus Convention into national law and entered into force on 14th February 2004. According to the UIG, agencies with obligation to provide information are prompted to actively and systematically inform the public to an appropriate extent about the environment. They should ensure that information is increasingly published on the Internet via databases (§7 UIG). As part of the reform of the federal system, the states have made use of their right of deviation and additionally adopted their own state laws in the field of environmental information. While most state law regulations are similar to the national law (UfU n.d.) Bremen and Hamburg further regulate the implementation of a central electronic environmental information system ( $§ 4$ BremUIG; $\$ 10 \mathrm{HmbTG}$ ). Document access as part of the EIA includes the dissemination of the comprehensive description and evaluation of environmental impacts and risk assessment in relation to the protected elements of the environment ${ }^{17}$ (§10 (2) No. 6 UIG). The Environmental Impact Assessment Act (UVPG) further regulates access to information on projects, plans, and programs subject to an environmental assessment. According to the UVPG ( $§ 6$ and $\S 9$ ) a project description, baseline description of the environment, expected significant environmental impacts, proposed mitigation measures, the most important alternatives and decision criteria, as well as other reports and recommendations relevant to the project have to be provided in the context of the public participation process. Deviating regulations in the states Brandenburg $(\S 4(3)$ BbgUVPG) and Lower Saxony ( $\$ 14 \mathrm{i} N \mathrm{NVPG}$ ) further regulate the web-based access to documents in the context of public participation in the SEA.

In contrast to other countries (e.g. Canada, Austria), the German UVPG and UIG so far provide no regulations for the establishment of a central database for standardized access and availability of documents and process information from environmental assessments (Odparlik et al., 2012). Nevertheless, to meet the requirements of the Council Directive 90/313/EEC on public access to environmental information, Germany and Austria have developed an environmental data catalogue (called Umweltdatencatalog UDK), a meta information system for identifying and locating available environmental information of authorities, institutions, and organizations (for example, ministries and federal and state agencies) (Voell, 2004). Based on an agreement between the German states and the federal government, the UDK was further developed and enhanced with a web interface called PortalU. Established in 2006, the environmental portal of Germany (PortalU) offered the public simple, user-friendly access to environmental websites, metadata, and subject databases of public bodies, including information on EIAs. When the management agreement between federal and state governments on the operation of the portal expired on 31st December 2014, the website was shut down (www.portalu.de). More recently, the Brandenburg country office of recognized conservation associations has launched a website providing information for the participation in environmental issues. The website is part of a research project called "Associations participation 2.0: e-participation in the associations participation" funded by the Federal Environmental Agency and the Federal Ministry for the Environment, Nature Conservation, Building and Nuclear Safety. The website provides a systematic and cartographic overview of participation opportunities but is restricted to the state of Brandenburg.

${ }^{17}$ According to §2 Abs. 3 Nr. 1 UVPG. 
It is believed, that as many as several thousand EAs have been performed in Germany (GHK, 2010). However, no comprehensive EA documentation exists (Bedke et al., 2006). There are no statistics or empirically robust studies on the number of EAs that have been completed. Since EIA procedures are generally integrated as a dependent part into existing licensing procedures and because the responsible authorities for the licensing process are the same as those for the EA process (Köppel et al., 2004), the responsibility for the EIA and, thus, the focal points for documents and procedural information can vary greatly (Voell, 2004).

\section{Method}

A case study analysis method, with a multiple-case design, was chosen (Yin, 2009), with the aim of evaluating access to EA documents and process information in Germany and the difficulty of a missing central database, as well as varying responsibilities. The analysis consists of two steps: Case selection and evaluation.

\section{1 Step 1: Case selection}

Considering that, as discussed above, publicly available information on EIAs can be accessed via web-based information systems, websites of lead agencies in the two sectors electricity grid expansion and federal road planning were identified for each planning level. As previous analyses have indicated that legal requirements to provide information have an important influence on the implementation of web-based information distribution, this study compares two planning fields with diverging requirements: electricity grid expansion, with mandatory online provision of information, and federal road planning, without specific regulations demanding web-based access to information. Plans and projects in both sectors are subject to environmental assessment (SEA and EIA) at three planning stages (with the exception of Berlin, Bremen and Hamburg, which lack sectoral spatial planning) and, at the same time, have a defined number of projects due to the respective federal requirements plan (FRP) (Table 6) that outlines the demand for a specific number of projects. These projects may have not necessarily entered the corridor planning (phase II) or approval phase (phase III), or they might be further divided into subprojects with separate approval procedures. Therefore, though the total number of conducted EIA/SEAs carried out is not known, there is a clear definition of who would be the lead agency and who should hold information once the planning process starts.

In the first step of the analysis, 87 lead agency and five transmission system operator (TSO) websites were identified for further evaluation. For the requirements for planning in phase I, three websites were identified: The two websites of the federal agencies BNetzA and BMVI and one website that is jointly run by four TSOs to provide information on the grid development plan. As the EnWG also requires the TSOs to publish information on their websites, the four websites of 50hertz, Amprion, Tennet and transnetBW were evaluated as well. For the corridor planning in phase II, a total of 36 websites were identified, where 34 are lead agencies for both electricity grid expansion and federal road planning and two are specific to transportation planning. Bremen and Hamburg did not provide information, as this planning stage does not exist in these federal city states. According to $\$ 16$ ROG Berlin falls under this exception as well, but provides information with the joined planning agency in Brandenburg. At phase III, 49 websites were identified. A great number of agencies are responsible for the plan approval procedure in both planning fields investigated here, but have assigned this task to different departments within the agency. As the provision of information can differ greatly among the departments, they were viewed as separate websites for better comparison of information provision in the two planning fields. Therefore, electricity grid expansion accounts for 19 websites and federal road planning for 30 websites. 
Documents for EA processes are also commonly provided in the agency offices but this form of information provision is not a subject of the analysis.

\subsection{Step 2: Evaluation}

The second step of the analysis is based on the proposition that the provided EA information on the Internet is of varying quality and can be evaluated using defined criteria.

In the time between March and July 2014, the 92 identified websites were analysed based on a previously developed review framework (Table 5) of relevant evaluation categories and criteria (Odparlik and Köppel, 2013). The framework, which has been adapted to account for the fact that EA in Germany is not a stand-alone process, allows for an evaluation in four review categories: Accessibility of information, notice of projects, provision of documents, and ongoing information about the status of the environmental assessment. Each of the categories contains best practice criteria for information access, derived from laws and for the most part from literature (e.g. Hanna and Noble, 2011; Findlay, 2010; Ryan et al., 2011; Sinclair et al., 2012; Claus et al., 2012; Odparlik et al., 2012), thereby going beyond the legislative requirements. To achieve ideal access to information, all criteria must be fulfiled. It must be noted that the analysis only represents a snapshot of a continuously changing source of information, as websites were analysed at one time and not over a period of time. Due to this fact, the analysis might miss information which had been provided for an active planning process, but which was deleted once the decision was made. This limitation of the analysis is discussed further below.

Table 5: Catalogue of criteria for case study assessment. Catalogue of criteria for case study assessment Source: Based on Odparlik and Köppel, 2013

Catalogue of criteria for case study assessment (Source: Based on Odparlik and Köppel, 2013)

\section{Accessibility of information}

- Gives basic information about the planning process, legal aspects and requirements (Clauset al., 2012)

- Appoints all institutions involved in the process (e.g. responsible authority, project proponent) with their specific contacts (including contact data, tasks and responsibilities in the process) (Claus et al., 2012, §9 UVPG)

- Gives instructions how to use the provided information (Odparlik et al., 2012)

- Provides additional services to improve the user experience (e.g. audio or video transmission of public hearings on the internet; reading aid) (Odparlik et al., 2012; Rau et al., 2012)

- Enables on-line entry of comments/opinions on the process or to the procedural documents (Odparlik et al., 2012)

Notice of projects

- Gives a systematic overview on ongoing and completed projects (Hanna and Noble, 2011)

- Provides a list (Odparlik and Köppel, 2013)

- Provides a filter function/search mask (Odparlik and Köppel, 2013)

- Provides basic information about a specific project (abstract) (Hanna and Noble, 2011; Findlay,2010; Claus et al., 2012)

- Supports the cartographic localization of projects (Hanna and Noble, 2011) 
Catalogue of criteria for case study assessment (Source: Based on Odparlik and Köppel, 2013) - continued

\section{Provision of documents}

- $\quad$ Contains documents of plan approval procedure

- $\quad$ Notice of intent/application (Hanna and Noble, 2011,§9 UVPG)

- Explanatory report (\$73 VwVfG)

- Other supporting documentation (additional studies, technical information, maps) (Hanna and Noble, 2011)

- Notice of hearings (Hanna and Noble, 2011)

- Transcripts and other material of public hearings (Odparlik et al., 2012)

- Public submissions/comments (Hanna and Noble, 2011; Claus et al., 2012)

- Response to public comments (reasons for in- or exclusion) (Odparlik et al., 2012; Rau et al., 2012)

- Planning approval notice (decision and reasons for the decision $\mathrm{p}$ list with assessment criteria) (Hanna and Noble, 2011; Claus et al., 2012)

- Contains all E(I)A documents (Hanna and Noble, 2011; Claus et al., 2012)

- Screening decision (Hanna and Noble, 2011; §9 UVPG)

- Scoping documentation (Odparlik et al., 2012)

- Impact studies (Hanna and Noble, 2011; Claus et al., 2012; §9 UVPG)

- $\quad$ Mitigation requirements/measures (\$9 UVPG)

- Monitoring and follow-up requirements (Hanna and Noble, 2011)

- Monitoring results (Hanna and Noble, 2011)

- $\quad$ Non-technical summary (§9 UVPG)

- Contains a list of unpublished documents (e.g. on the basis of copyright protection by consultants) (Hanna and Noble, 2011; Findlay, 2010)

Ongoing information about the status of the environmental assessment

- Includes an illustration of the general sequence of the process and the current status of progress (Claus et al., 2012)

- Offers digital information services (e-mail alerts, RSS feeds) in order to follow the activities within the process and provide fair notice (Odparlik et al., 2012)

\section{Case Study: EA for Energy Grid and Federal Road Projects}

In federal road as well as electricity grid expansion planning, there is a legal requirement to define the demand of developments on federal level (Grid Development Plan, Federal Transport Infrastructure Plan (FTIP)). Both planning fields require corridor planning to delineate the route corridor of either the power line or the federal road ( $\$ 1 \mathrm{RoV}$ - Regional Planning Decree; $§ 15$ ROG - Spatial Planning Act; §4 NABEG; §16 FStrG) and final permission is granted in a plan approval procedure (§§72-78 VwVfG - Administrative Procedures Act; §§18ff. NABEG). All three levels are subject to either SEA or EIA (see UVPG) and therefore, apart from other regulations, require for public participation (Table 6).

The necessity for the electricity grid expansion results from the publicly debated "Energiewende" (energy transition towards more renewable energies), which lead to broad media coverage and the aim of a transparent planning process (e.g. EU Grid declaration on transparency and public participation - Renewables Grid Initiative 2012). The Renewable Energies Act (EEG) mandates that renewable energy should account for at least $50 \%$ of production by 2030 and gives priority to feeding in and transporting electricity generated from renewables. These targets can only be met by expansion of the extra-high voltage grid. The legal framework (Table 6) is provided by the Energy Industry Act (EnWG), whereas planning and approval procedures are defined in the Power Grid Expansion Act 2009 (EnLAG) and the Grid Expansion Acceleration Act 2011 (NABEG). While the older process of transport infrastructure planning was initially used as a role model (SRU, 2011), the planning process for energy grids now consists of five consecutive steps (Table 6) with several opportunities for public involvement. "The aim is to equip the network landscape for the 
switch to renewable energy sources as quickly as possible and to reach the necessary decisions together with society as a whole" (BNetzA n.d.).

The EnLAG contains 23 projects that have already been assigned a high priority status for future energy supply and necessity for the energy economy in the year 2009. Planning of these projects lies in the responsibility of the federal states. Furthermore, every three years the Federal Ministry for Economic Affairs and Energy (BMVI) passes the FRP according to NABEG. The FRP 2013 contains 36 projects with high priority. 16 projects are transnational or transboundary projects with BNetzA (Bundesnetzagentur - Federal Network Agency) as lead agency for the corridor planning and planning approval; the federal states are responsible for the other projects which do not cross borders. The 36 projects can be split into single measures in the later planning stages; e.g. Project No. 8 Brunsbüttel - Bundesgrenze (DK) is split into five single sections with separate planning procedures.

For grid expansion, §12b (3) and §12c (3) EnWG require the BNetzA and the TSOs to publish information on their websites; for six weeks the Grid Development Plan, the environmental report, and additional information can be downloaded from the website of the BNetzA, in addition to the printed documents that can be viewed at the office of the BNetzA. According to the NABEG, documents of phase II ( $\S 9$ (4) NABEG) and documents of phase III (§22 (4) NABEG) have to be published on the Internet for one month as well as being made available at the offices of the agencies. Transportation infrastructure planning for federal roads in Germany is regulated in the Highway Expansion Act (FStrAbG) and Federal Highway Act (FStrG). Responsibility for the planning requirements lies with the German Federal Ministry of Transport (BMVI - Bundesministerium für Verkehr und digitale Infrastruktur). The FTIP combines the assessment of concrete network needs in transport corridors with the identification of priority projects based on cost-benefit analysis (Fischer, 2006). The current FTIP (2003) defines a financial framework of 77.5 Billion $€$ for the preservation, development, and new construction of federal roads (autobahn and state highways). A total number of 2,590 projects are categorized by urgent demand $(1,588)$ and further demand $(1,002)$. 358 of these projects are labelled as having a high ecological risk or place a special planning order on nature conservation. Although the UVPG places a requirement on the National Transport Infrastructure Plan to undergo SEA, the 2003 plan has not yet been subject to SEA since the law on SEA only came into force 2004. Nevertheless, impacts to the environment have been recognized with appropriate habitats estimation according to the EU Habitats Directive (Council Directive 92/43/EEC of 21 May 1992 on the conservation of natural habitats and of wild fauna and flora) and an ecological risk analysis (Fischer, 2006) focusing on cultural landscapes, highly sensitive areas, and unfragmented traffic areas.

The legislative process is outlined by the National Transport Infrastructure Plan and concludes with the assessment of a project's necessity. Once approved, the project is included in the final list in the Annex to the Highway Expansion Act. Unfortunately, this Annex is not publicly available in the Internet and the BMVI as well did not allow access to that plan when requested ("simply too many projects included"). Nevertheless, the procedure outlined for the National Transport Infrastructure Plan 2015 promises several steps of public participation and a transparent planning process. The subsequent delineation of the route corridor is decided in the spatial planning procedure (ROV, with EA and public participation) and/or the line determination procedure (with EA if the project did not undergo a spatial planning procedure). As for grid extension, final decision is granted in the plan approval procedure (Table 6). 


\begin{tabular}{|c|c|c|}
\hline & Electricity grid expansion planning & Federal road planning \\
\hline $\begin{array}{l}\text { Planning } \\
\text { phase I } \\
\text { requirement } \\
\text { planning }\end{array}$ & $\begin{array}{l}\text { Legal basis: } \S \S 12 a-e \text { EnWG; } \S \S 4-17 \text { NA- } \\
\text { BEG } \\
\text { Responsibility: BNetzA + TSOs (step 1+2); } \\
\text { BMWI (step 3) } \\
\text { Steps: } \\
\text { - } \quad \text { Scenario Framework } \\
\text { - } \quad \text { Grid Development Plan with Environ- } \\
\text { mental Report (§12c (2) EnWG) } \\
\text { - } \quad \text { Federal Requirements Plan (subject to } \\
\quad \text { SEA - } 112 e(5) \text { EnWG; } \S \S 6,8 \text { NABEG) }\end{array}$ & $\begin{array}{l}\text { Legal basis: FStrAbG; } \\
\text { Responsibility: BMVI } \\
\text { Steps: } \\
\text { - } \quad \text { Scenario Framework } \\
\text { - } \quad \text { Federal Transport Infrastructure Plan } \\
\quad \text { (subject to SEA - §19b UVPG) } \\
\text { - } \quad \text { Requirements Plans as Annex to } \\
\text { FStrAbG }\end{array}$ \\
\hline $\begin{array}{l}\text { Planning } \\
\text { phase II } \\
\text { corridor } \\
\text { planning }\end{array}$ & $\begin{array}{l}\text { Case 1: lines according to NABEG not } \\
\text { crossing a boarder \& lines acc. to EnLAG } \\
\text { Legal basis: } § 1 \text { (11) RoV; } § 15 \text { ROG* } \\
\text { Lead agency: federal state planning au- } \\
\text { thorities } \\
\text { (subject to EIA - } \S 3 \text { + annex } 1 \text { UVPG) } \\
\text { Case 2: transboundary lines acc. To NA- } \\
\text { BEG } \\
\text { Legal basis: } \S ~ 4-17 \text { NABEG } \\
\text { Lead agency: BNetzA } \\
\text { (subject to SEA - } 55 \text { (2) NABEG; } § 14+\text { an- } \\
\text { nex } 3 \text { UVPG) } \\
\text { * Does not apply for Berlin, Bremen and } \\
\text { Hamburg }\end{array}$ & $\begin{array}{l}\text { Legal basis: } § 1 \text { (8) RoV; } § 15 \text { ROG* } \\
\text { Lead agency: federal state spatial plan- } \\
\text { ning authorities } \\
\text { (subject to EIA - } \S 3+\text { annex } 1 \text { UVPG) } \\
\text { Line determination } \\
\text { Legal basis: } § 16 \text { FStrG } \\
\text { Lead agency: BMVI } \\
\text { (subject to EIA if no spatial planning pro- } \\
\text { cedure) }\end{array}$ \\
\hline $\begin{array}{l}\text { Planning } \\
\text { phase III } \\
\text { plan ap- } \\
\text { proval pro- } \\
\text { cedure }\end{array}$ & $\begin{array}{l}\text { Case 1: lines according to NABEG not } \\
\text { crossing a boarder \& lines acc. to EnLAG } \\
\text { Legal basis: } \$ 43 \text { ENWG; } \S ~ 72-78 \text { VwVfG } \\
\text { Lead agency: federal state planning au- } \\
\text { thority } \\
\text { (subject to EIA - } \S 3 \text { + annex } 1 \text { UVPG) } \\
\text { Case 2: transboundary lines acc. To NA- } \\
\text { BEG } \\
\text { Legal basis: } \$ 43 \text { ENWG; } \S 18 f f . ~ N A B E G \\
\text { Lead agency: BNetzA } \\
\text { (subject to EIA - } 33+\text { annex } 1 \text { UVPG) }\end{array}$ & $\begin{array}{l}\text { Legal basis: } § 17 \text { FStrG; } \S \S 72-78 \text { VwVfG } \\
\text { Lead agency: federal state road construc- } \\
\text { tion agency and/or middle level author- } \\
\text { ity, commissioned by BMVI } \\
\text { (subject to EIA - } \S 3+\text { annex } 1 \text { UVPG) }\end{array}$ \\
\hline
\end{tabular}

In the transport sector there are only a few specific regulations regarding web-based access to information. On the first planning level, inclusion of public participation in the drafting of the FTIP 2015 shows the intent to provide access to the FTIP and FRP. On the second level, with the exception of Bavaria (Art. 25 BayLplG), there are no further regulations in the spatial planning law to publish information on the Internet. The same holds for the level of plan approval proceedings.

\section{Results}

Results showed diverse performance in the provision of information and online access to documents, not only amongst planning levels or websites on each level, but also for each individual project. Therefore, the provision of documents needs to be viewed separately from the general interpretation of performance. 
Overall fulfilment of criteria in the categories accessibility of information, notice of projects, and ongoing information was highest for agency websites in phase I and lowest for phase II. The TSO websites on average fulfilled about $60 \%$ of the previously defined criteria, proving to be a valuable additional source of information. Agencies at phase II showed an average fulfilment of about $20 \%$ of the criteria per website and, therefore, a significantly lower performance than agencies and TSOs in phase I. Agency websites in Mecklenburg-West Pomerania, Lower Saxon Ministry, Berlin, and Brandenburg showed a fulfilment of more than half of the set criteria, which might be explained by the legal requirement in those states to provide web-based access to SEA documents. On the third planning level, agency websites showed an average fulfilment of one third of criteria per website. Lower Saxony showed outstanding performance with around $60 \%$ of criteria met on agency websites for both planning fields.

For phase II, the majority of agencies ( 34 of 36) are responsible for both electricity grid expansion as well as federal road planning projects. As websites addressed both planning sectors, a differentiated analysis was not possible for this phase (see Table 7 - Table 9 and Figure 8). Therefore, comparison of both planning sectors was based on the results for phases I and III and revealed only minor differences.

\subsection{Accessibility of information}

The analysis showed that basic information about the general planning process, its legal aspects, and requirements were provided on the majority of websites (app. 80\%) across all planning phases and for both sectors (Table 7). Nevertheless, basic information on the process of EIA or SEA was only provided on one third of the websites. Also, simple instructions about how to use the provided information were given on one-third of the websites, equally distributed among the sectors but highest for phase III (app. 44\%).

This analysis mainly investigated the websites of responsible authorities. Therefore, it does not seem surprising that in the majority of cases the contact information of the responsible authority has been provided. In many cases a specific contact person within the department was named. The comparison between the two planning fields shows that for the federal road planning sector a smaller number of websites (app. 20\%) provide contact information on the project proponent. This can be explained by the fact that the project proponent is the responsible authority at the same time; a fact which was not explained for the public. Information on other involved agencies or experts was rarely provided (app. 10\%).

IT services to improve the user experience were provided on about $10 \%$ of the websites, including explanatory videos of the planning process, (3D) simulations, glossaries and FAQ compilations, reading aids for EIS, content in English, and sign language and/or simple language. One website even provides the option to have text read out loud. E-participation in form of online comments was only used on four websites and only in phase I and phase II of the planning process, though equally for both sectors. 
Table 7: Results on the accessibility of information in the investigated cases Source: Author.

\begin{tabular}{|c|c|c|c|c|c|c|}
\hline \multirow{2}{*}{$\begin{array}{l}\text { Criteria for the accessibility of } \\
\text { information }\end{array}$} & \multicolumn{2}{|c|}{ Phase I } & Phase II & \multicolumn{2}{|c|}{ Phase III } & \multirow[t]{2}{*}{ TSOs } \\
\hline & Grid & Transp. & $\begin{array}{l}\text { Grid + } \\
\text { Transp. }\end{array}$ & Grid & Transp. & \\
\hline Total number of websites & 1 & 1 & 36 & 19 & 30 & 5 \\
\hline \multicolumn{7}{|c|}{ Gives basic information about the planning process, legal aspects and requirements: } \\
\hline General Planning Process & 1 & 1 & 14 & 14 & 27 & 5 \\
\hline $\mathrm{EA}$ & 0 & 1 & 7 & 7 & 13 & 2 \\
\hline \multicolumn{7}{|c|}{ Appoints all institutions involved in the process with their specific contacts: } \\
\hline Responsible authority & 1 & 1 & 17 & 17 & 25 & 3 \\
\hline Project proponent & 1 & 1 & 7 & 7 & 5 & 5 \\
\hline other & 1 & 0 & 2 & 2 & 3 & 2 \\
\hline $\begin{array}{l}\text { Gives instructions how to use the } \\
\text { provided information }\end{array}$ & 0 & 1 & 2 & 8 & 10 & 1 \\
\hline $\begin{array}{l}\text { Provides additional services to im- } \\
\text { prove the user experience }\end{array}$ & 1 & 0 & 3 & 0 & 1 & 3 \\
\hline $\begin{array}{l}\text { Enables on-line entry of com- } \\
\text { ments/opinions }\end{array}$ & 1 & 1 & 2 & 0 & 0 & 0 \\
\hline
\end{tabular}

\section{2 Notice of projects}

In both planning sectors, more than $70 \%$ of the websites provide information on ongoing planning processes and thereby indicate where participation might be possible. In the intermediate planning phase II less than $40 \%$ of the websites inform visitors about ongoing and completed projects. Also the number of websites providing information on completed electricity grid expansion projects is significantly smaller (less than $50 \%$ ) which might be ascribed to the young planning field. Project information labelled as ongoing does not necessarily indicate the exact planning stage, e.g. screening or participation, and therefore does not allow conclusions to be drawn about which information should be there. Due to this omission, the documents presented here cannot be further categorized by ongoing and completed projects, even though the provision of documents for ongoing projects is most interesting in terms of public participation.

While most of the websites list ongoing and completed planning processes, none provided a specific filter or search function to browse through the projects.

Table 8: Results on the notice of projects in the investigated cases.

\begin{tabular}{|c|c|c|c|c|c|c|}
\hline \multirow[t]{2}{*}{ Criteria for the notice of projects } & \multicolumn{2}{|c|}{ Phase I } & \multirow{2}{*}{$\begin{array}{l}\text { Phase II } \\
\text { Grid + } \\
\text { Transp. }\end{array}$} & \multicolumn{2}{|c|}{ Phase III } & \multirow[t]{2}{*}{ TSOs } \\
\hline & Grid & Transp. & & Grid & Transp. & \\
\hline Total number of websites & 1 & 1 & 36 & 19 & 30 & 5 \\
\hline \multicolumn{7}{|l|}{ Gives a systematic overview on: } \\
\hline Ongoing projects & 1 & 1 & 13 & 13 & 21 & 5 \\
\hline Completed projects & 1 & 1 & 10 & 8 & 18 & 3 \\
\hline Provides a list with projects & 1 & 0 & 11 & 15 & 23 & 5 \\
\hline
\end{tabular}




\begin{tabular}{|l|l|l|l|l|l|l|}
\hline Criteria for the notice of projects & \multicolumn{2}{|l|}{ Phase I } & Phase II & Phase III & TSOs \\
\cline { 2 - 7 } & Grid & Transp. & $\begin{array}{l}\text { Grid + } \\
\text { Transp. }\end{array}$ & Grid & Transp. & \\
\hline $\begin{array}{l}\text { Provides a filter function/search mask } \\
\text { to sort projects }\end{array}$ & 0 & 0 & 0 & 0 & 0 & 0 \\
\hline $\begin{array}{l}\text { Provides basic information about a } \\
\text { specific project (abstract) }\end{array}$ & 1 & 1 & 10 & 9 & 7 & 5 \\
\hline $\begin{array}{l}\text { Supports the cartographic localization } \\
\text { of projects }\end{array}$ & 1 & 0 & 4 & 1 & 0 & 2 \\
\hline
\end{tabular}

While the provision of a short abstract was common in about $60 \%$ of the websites for electricity grid expansion planning in phase III, only $30 \%$ of phase II agency websites and federal road planning websites stay had this feature. Also a mapped view of project locations was rarely available (overall below $10 \%$, none in the federal road planning sector). One phase II agency uses the potential of their regional land cadaster to reference regionally relevant linear projects like grids and roads. Unfortunately there is no open access and a CD containing that information is only available at a price of $123,50 €$. The federal network agency presents a good example, providing maps of Germany with electricity grid expansion planning according to the FRP and the Power Grid Expansion Act 2009 (www.netzausbau.de).

\section{3 Provision of documents}

The category "provision of documents" refers to documents of the planning approval process (e.g. regional planning procedure or plan-approval procedure) and the EA documents. While 40 of the 92 investigated websites do not provide any documents, among those that do the provision of documents varies greatly between the different planning phases.

The two phase I agency websites for electricity grid expansion and transport planning both provide general approval process documents. As the FTIP has never been subject to SEA before, SEA documents are only provided by the federal network agency.

For corridor planning (phase II) one third of the agencies provide process documents for 39 projects (14 federal road and 25 electricity grid expansion projects). Impact assessment documents are only provided by six agencies. Five publish only their screening decisions and these are often restricted to negative screening decisions. Among the 12 agencies that provide documents at phase II, planning decisions (24) and supporting documents like maps (27) were most commonly provided. At the same time, documentation related to public participation was rarely provided. Less than $20 \%$ of the websites provide a notice, transcripts or other material of public hearings, public comments, response to those comments, or reasons for in- or exclusion. The six agencies with EA documents provided impact studies for one quarter of the projects, while none of the agencies provided information on monitoring requirements or results (Fig. 1). 


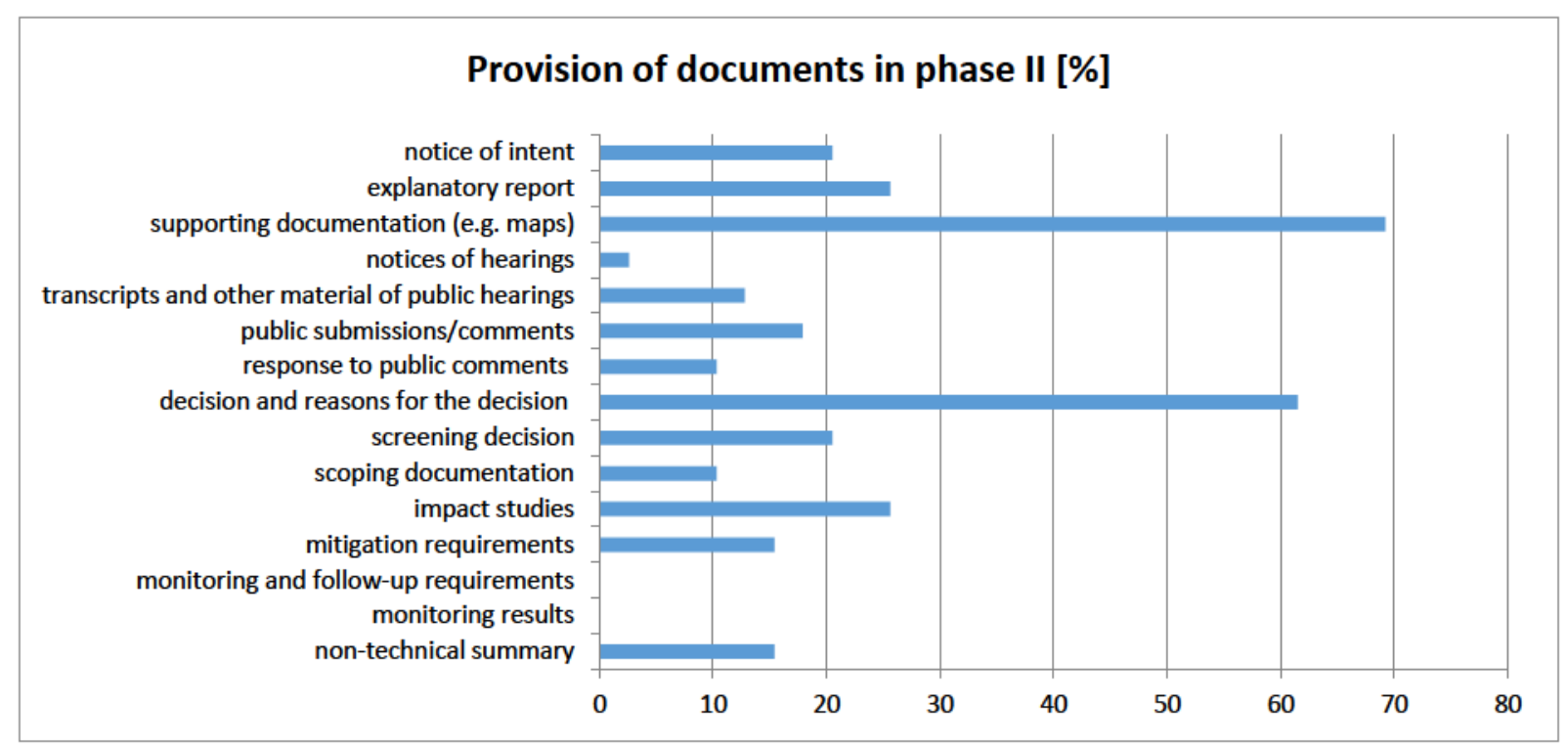

Figure 8: Provision of documents in the phase II (corridor planning) in both sectors.

In the third planning phase, almost three quarters of lead agency websites provide documents on the plan approval procedure for 282 cases (54 electricity grid expansion planning; 213 federal road planning). Nearly half of the agency websites, three times as many as in the second planning phase, provide EA documents as well. The analysis shows (see Fig. 2) that more than $50 \%$ of the websites specific to electricity grid expansion planning publish a notice of intent, explanatory report, and supporting documentation. About $44 \%$ use the website to announce the planning decision and reasons for it. This number is significantly lower than, for example the supporting, documentation, but might be explained by the fact that not all the projects have yet had a final decision issued. For websites with separation of ongoing and completed projects, the provided documents for a completed project were often restricted to the planning decision. For the federal road planning, more than $60 \%$ used the websites to publish the decision and reasons for it, as well as supporting documentation.

Similar to the second planning phase, the provision of information surrounding the process of public participation was relatively low compared to the other categories. Of the agencies responsible for the grid expansion planning, $32 \%$ publish notices of hearings on their websites. Only $16 \%$ of the websites for federal road planning do this. Most of the websites have a general register of public announcements or a digital version of their official gazette that announces hearings, but fail to provide that information (e.g. via link) on the subpage with the project information. 


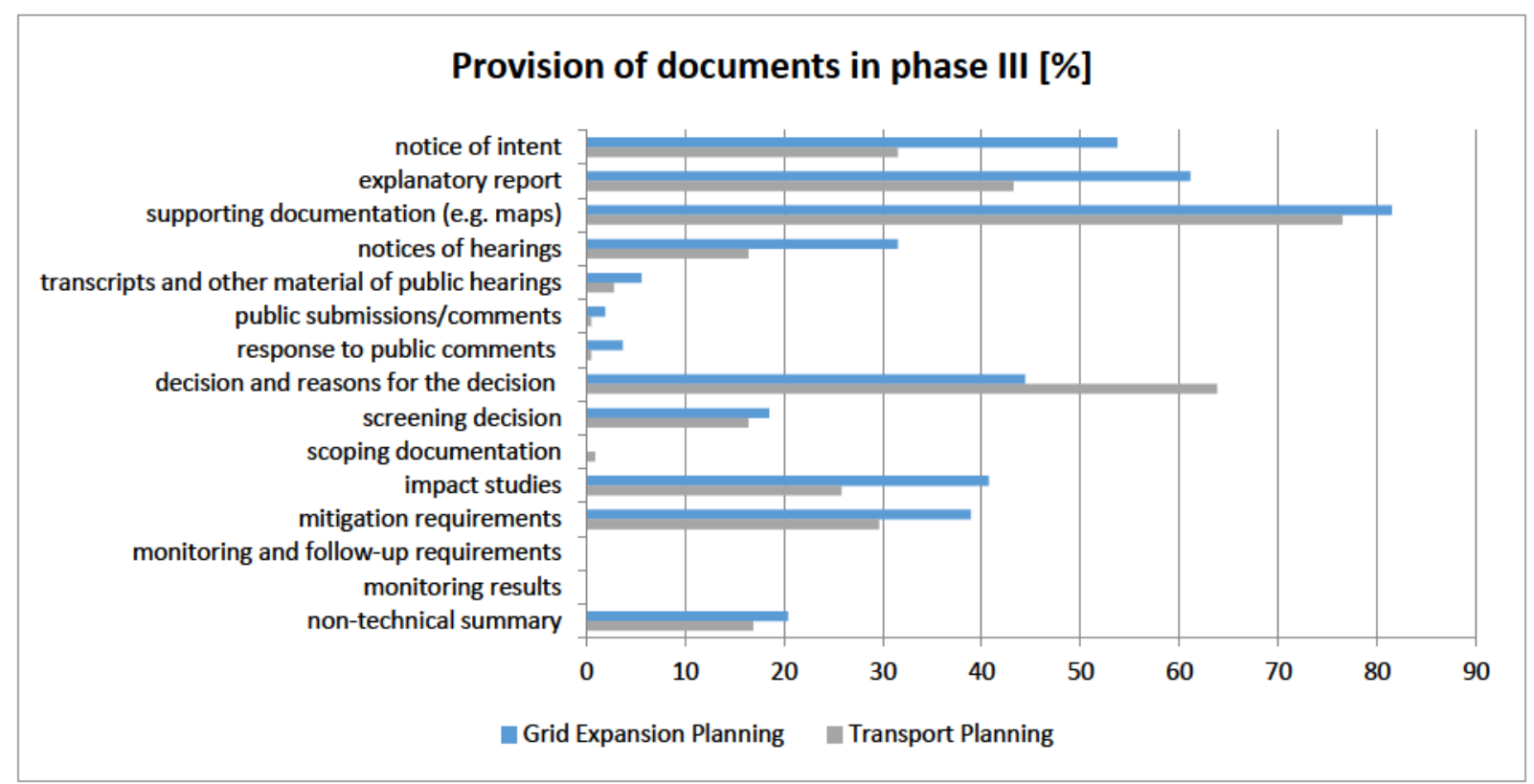

Figure 9: Provision of documents in the phase III (plan approval procedure) in the two sectors: Electricity grid expansion planning (blue) and federal road planning (light grey).

Figure 9 demonstrates that the provision of EA documents is focused on the impact studies and mitigation requirements in both sectors, with a generally higher information provision in electricity grid expansion planning. In the federal road planning sector the requirements of mitigation measures are published even more frequently than the impact studies. A non-technical summary of the impact study is required by UVPG but less than a quarter of the websites provide this. Between

$15 \%$ and $20 \%$ of websites provide information on screening decisions (decision whether an environmental assessment has to be carried out); often on negative screening decisions within the general announcements, sometimes with a registry on screening decisions. Scoping information (definition of the scope of the assessment) is only provided for two federal road projects. Similar to phase II, phase III websites also did not provide any documents on monitoring and follow-up requirements or monitoring results.

\section{4 Ongoing information}

Across all planning phases less than a quarter of websites illustrated the general planning sequence and/or the current status of the process (see Table 9). A good example is presented by the TSO transnet BW (www.transnetbw.de) that supports project information with a timeline of the planning process. As the indication of the status alone would require visiting the websites on a regular basis, one out of four websites announces new information via e-mail alerts, RSS feed, Twitter, or Facebook. 50 hertz (www.50hertz.com) even provides this service specific to each project. 
Table 9: Results on the provision of ongoing information in the investigated cases.

\begin{tabular}{|l|l|l|l|l|l|l|}
\hline \multirow{2}{*}{$\begin{array}{l}\text { Criteria for the provision of ongo- } \\
\text { ing information }\end{array}$} & Phase I & Phase II & Phase III & TSOs \\
\cline { 2 - 8 } & Grid & Transp. & $\begin{array}{l}\text { Grid + } \\
\text { Transp. }\end{array}$ & Grid & Transp. & \\
\hline Total number of websites & 1 & 1 & 36 & 19 & 30 & 5 \\
\hline $\begin{array}{l}\text { Includes an illustration of the general } \\
\text { sequence of the process and the current } \\
\text { status }\end{array}$ & 1 & 1 & 5 & 5 & 4 & 5 \\
\hline $\begin{array}{l}\text { Offers digital information services (e- } \\
\text { mail alerts, RSS feeds) in order to follow } \\
\text { the activities within the process and } \\
\text { provide fair notice }\end{array}$ & 1 & 1 & 7 & 3 & 8 & 3 \\
\hline
\end{tabular}

\section{Discussion}

Analysis of Germany's performance in the online dissemination of planning information in the electricity grid expansion and federal road planning sectors shows a diverse range of interpretations of the legal regulations. Supporting the first proposition, that publicly available information on environmental assessments can be accessed via web-based information systems, analysis of both planning sectors has shown that more than $70 \%$ of the websites provide information on ongoing planning processes.

Agency websites in states with more specific online access regulations did not show significantly better performance. The initial assumption that the new planning field might show better performance in the provision of information due to its media attention and additional regulations has not materialized for all planning phases. In the provision of information on completed projects, electricity grid expansion planning even showed lower performance than the federal road planning sector, but that may be explained by the fact that it is simply a young planning field with smaller number of projects that have actually been completed.

\section{1 Accessibility of information}

Layperson-expert tensions, or the so-called "expertise barrier" (the lack of scientific, technical or political knowledge; Parthasarathy, 2010, p. 355), is a common phenomenon in environmental decision-making processes (Hourdequin et al., 2012). Wiklund (2011, p. 172) showed "that the insufficient knowledge of the EA process and the opportunities of participation is the single most important reason for non-participation." Consequently, the first step in overcoming this barrier is the transparent provision of planning documents as well as education on the planning process and how to locate, interpret, and effectively utilise this information. Results indicate a clear need for improvement in this regard, especially in the provision of basic knowledge about the EIA and SEA process.

To increase the transparency of the planning process, a website should list all institutions involved in the process (e.g. responsible authority, project proponent, and other experts like the environmental planner) with their specific contacts, tasks, and responsibilities (Claus et al., 2012; §9 UVPG). While this information was provided for the majority of the lead agencies, improvement is needed for the contact information of the project proponent. There is a clear need to improve the information on the responsibilities within the planning process. Especially in the federal road planning sector, the fact that the lead agency and project proponent are often the same agency needs to be clearly communicated to increase transparency. Contacts for independent experts 
could be provided on a voluntary basis, especially when the participation process faces trust issues.

The planning documents published online needs improvement in the area of information on and in support of public participation. This deficit is reflected in the infrequent use of participatory web 2.0 elements. For most of the websites investigated, information provision represents a oneway process where dialogue (two-way approach) is limited to public hearings and informational events and is rarely offered on websites via comment functions. International registries have shown the use of a variety of IT services like audio recordings of hearings or explanatory videos to improve the user experience (Odparlik and Köppel, 2013). Yet only four of the investigated websites allow an online posting of comments.

Only eight sites allow rapid localization of ongoing assessments using maps. Just $10 \%$ use other IT services such as 3D simulations, explanatory videos or question pools (FAQs). Even though Germany is often seen as a role model in the implementation of the "Energiewende" and one of the leading countries in environmental information science, there is both a need and potential for better implementation in the German administrative procedures and for Germany to learn from international approaches when it comes to the implementation of IT services in support of e-participation. One advanced example is provided by the US Bureau of Land Management Comment Submission Wizard, which allows marking and direct comments on specific text passages in the planning document. Also the use of audio recordings of hearings and audio webcasts (e.g. Canadian Environmental Assessment Registry; Mackenzie Valley Review Board) can further improve the process of participation.

As approaches of e-participation are generally limited to active planning processes and this analysis only presents a snapshot of the situation during the time of investigation, past applications of e-participation might not have been recognized, e.g. when the specific websites have been taken down once the procedure was completed. Nevertheless, as Schulze-Wolf and Köhler (2008) have shown, e-participation has been successful in the past, for example by the Lower-Saxony Authority for Road Construction and Traffic. In the regional impact assessment procedure for the A 22 motorway the public was informed and able to comment on different alternative routes of the proposed project via a web-based information portal. While in the presented case, e-participation was not utilised in the expected intensity (mainly due to organizational barriers as e.g. habits, paper-based workflows, or missing human resources), the authors argued that the degree of participation can be enhanced with targeted introduction and education about the instruments of eparticipation. Compared to traditional forms of participation using analog media, with high production costs due to the large amounts of impact assessment documents and the logistic effort of providing access, e-participation has the benefit of reaching considerably more participants in a significantly larger area with the same financial outlay. Additionally, the ability to get involved (e.g. via commenting) through forms of e-participation eliminates the otherwise restricting factors of time and place (Schulze-Wolf and Köhler, 2008).

Readability of documents was not part of the scope of this analysis, nevertheless it constitutes an important aspect which should not be neglected in the discussion about access to information, as formal access to documents does not necessarily lead to substantive accessibility (Hourdequin et al., 2012). Guidelines on plain language and document readability as for example published by the Washington State Department of Transportation show promising approaches.

\section{2 Notice of projects}

A systematic overview of ongoing planning processes with EA provides initial information where participation might be possible (Hanna and Noble, 2011). This fact is well recognized and 
reflected by the more than $70 \%$ of websites informing visitors about ongoing planning processes. Judging the amount of provided information (number of cases) through a comparison with the FRP proved to be difficult. While the Transport Infrastructure Plan, for example, defines 2590 projects of urgent and further demand, the investigated websites only provided information on 213 projects in the third planning phase. While one might initially see that as a poor provision of information, not all of the projects defined in the requirements plan have necessarily entered the corridor planning or approval phase yet. Nevertheless, information on the respective planning status is often missing, which makes it impossible to draw conclusions about whether all existing documents are actually provided for download. Previous analyses (Odparlik and Köppel, 2013) and conversations with lead agency staff have indicated that provision of information and sensitive planning documents is often restricted by privacy policies (e.g. on the basis of trade secrets). One approach to deal with this restrictions, and nonetheless support a transparent planning process, is to use a list of unpublished documents. For example, the California Energy Commission provided a Docket Log, listing all documents filed in a proceeding. This approach was not used by any of the investigated German agencies and TSOs.

\section{3 Provision of documents}

The analysis showed that EA documents are only provided by one third of agency websites and, even on these websites, the types of documents provided differs from case to case. It must be noted that the analysis only represents a snapshot of a continuously changing source of information, as websites were not analysed over a period of time. Due to this fact, the analysis might miss information which had been provided for an active planning process but which was deleted once the decision was made. This limitation is apparent in the amount of documents provided for completed planning procedures: documents in addition to the planning decision are often not supplied. While limited agency web space might be a possible reason, further research needs to be done in this regard. As this analysis is restricted to online access of documents, the presented results do not reflect the document provision in offices of lead agencies.

Impact studies and documents on mitigation requirements were most frequently provided, but were still found in less than $40 \%$ of agency websites in phase III. It must be mentioned that mitigation requirements can result from other environmental planning instruments, e.g. the impact regulation under nature conservation law or the EU habitats directive. Scoping information was only provided in two cases. This is not surprising as the German Planning process does not foresee participation of the public at the scoping stage as the US NEPA does (Köppel et al., 2012). Nevertheless, next to the evaluation of alternatives and gathering of baseline environmental information, this step is also intended for gathering input and identifying affected parties (Slotterback, 2009). Access to scoping protocols could be used by the public and foster the contribution of comments, thereby allowing different values and interests to be integrated into the project at an early stage of planning. Furthermore public involvement can provide information that might have been overlooked otherwise and thereby promote consensus around environmental impacts (Baker and Rapaport, 2005).

\section{4 Ongoing information}

During the course of the planning process, it is important for the user to stay informed about the progress and status of the environmental assessments. While a quarter of websites already uses IT-services like RSS feeds to keep the interested public informed, their use should be further increased and a clear indication of the overall planning sequence and the current status needs to be added. 


\section{5 A central portal}

Besides some basic explanation of the two later planning stages, information provision on the two federal agency websites is restricted to requirement planning (phase I), even though they would naturally lend themselves as central portals or meta-information systems as newly requested by the EU or applied internationally, e.g. in Canada, USA, or Austria. A central portal might lead to reduction in the number of agencies with different interpretation and understanding of information provision. A central database on EA information offers online public access to data, $24 \mathrm{~h} \mathrm{a}$ day from anywhere, and these benefits are not restricted to improved public participation. Such a central database, for example, allows for easier consideration of cumulative effects (King et al., 2012) as projects in one area are referenced within the same database and can be rapidly localised. It can support the goal of tiering on vertical and horizontal levels (Wiegert, 2009), as previous findings can easily be accessed, minimizing the costs and duration of assessments. Additionally, it can provide a database for research on EA, as seen in Austria where the database is used every three years for extensive analysis on their EIA implementation and performance (Odparlik et al., 2013). Implementation of these forms of e-Government, "calls for an integration and networking of public authorities, which will have a tremendous impact on organizational structures and responsibilities, on data access and on the way governmental work will be performed in the future" (Wimmer, 2002), which makes a common standard inevitable.

\section{Conclusion}

Analysis of Germany's performance in online dissemination of planning information in the electricity grid expansion and federal road planning sectors shows a diverse range of interpretations of the legal regulations. A common standard — what and how to provide access especially to documents within the EIA and SEA procedure - is missing. Here applied analysis criteria might offer a starting point. Information provision needs to be improved, especially in terms of public participation and to provide a common basis for consensus building. For example, the planning status and general knowledge what information can be expected at each stage should be clearly indicated. If documents have been prepared but online access is denied, this should be communicated as well. Furthermore, access to scoping protocols could foster public contribution of comments and thereby allow different values and interests to be integrated into the project at an early stage of planning (Baker and Rapaport, 2005). Implementation of a central portal would further support the establishment of a common standard.

For now, some questions remain. What factors currently drive and hinder federal agencies from consistently publishing information on planning processes, especially EA documents, on their websites? How do agencies with insufficient online information provision explain their shortcomings? Is it the missing standard, conflicting laws on data protection, lack of experience with the manifold IT services or simply a question of power relations and costs? 


\section{References}

Baker, D.; Rapaport, E. (2005): The science of assessment: Identifying and predicting environmental impacts. In: Hanna, K.S. (ed.): Environmental Impact Assessment: Practice and Participation. Oxford, Oxford University Press.

Bartlett, R.V.; Kurian, P.A. (1999): The theory of environmental impact assessment: Implicit models of policy making. Policy \& Politics 27(4): 415-433.

BayLplG (Bayerisches Landesplanungsgesetz) [Bavarian State Planning Act] (2012). Online: https://www.region-suedostoberbayern.bayern.de/verband/bayLplG_2012.pdf [Accessed 23.09.2014].

BbgUVPG (Brandenburgisches Gesetz über die Umweltverträglichkeitsprüfung) [Environmental Impact Assessment Act of Brandenburg] 2002. Revised 2010. Online: http:// www.bravors.brandenburg.de/sixcms/detail.php?gsid1/4land_bb_bravors_01.c.47292.de [Accessed 23.09.2014].

Bedke, N.; Dopfer, J.; Kellert, S.; Kober, D. (2006): Evaluation des Gesetzes über die Umweltverträglichkeitsprü-fung. Auswirkungen auf den Vollzug des Umweltrechts und die Durchführung von Zulassungsverfahren. UVP-Report 20(5): 211-214.

BNetzA (Bundesnetzagentur) [Federal Network Agency] (n.d.): How it works: Grid expansion in five steps. Online: http://www.netzausbau.de/cln_1411/EN/Verfahren/Verfahren-node.html [Accessed 23.09.2014].

BremUIG (Umweltinformationsgesetz für das Land Bremen) [Environmental Information Act of Bremen] (2005). Online: http://www.bauumwelt.bremen.de/sixcms/media.php/ 13/BremUIG.pdf [Accessed 23.09.2014].

Claus, F.; Hampe, J.; Hinzke, L.; Lühr, K.; Paust, A.; Renkamp, A.; Versteyl, A. (2012): Mehr Transparenz und Bürgerbeteiligung. Prozessanalysen und Empfehlungen am Beispiel von Fernstraßen, Industrieanlagen und Kraftwerken. Vorabversion der Studie. Bertelsmann Stiftung, Gütersloh. Online: http://www.dialoggestalter.de/fileadmin/Media/Downloads/Studie- Buergerbeteiligung-Prozessanalysen-Infrastruktur.pdf [Accessed 23.09.2014].

DIRECTIVE 2014/52/EU OF THE EUROPEAN PARLIAMENT AND OF THE COUNCIL of 16 April 2014 amending Directive 2011/92/EU on the assessment of the effects of certain public and private projects on the environment [2014] 0J L124/1. Online: http://eur-lex.europa.eu/legal-content/EN/TXT/PDF/?uri1/4CELEX:32014L0052\& from $1 / 4$ EN [Accessed 23.09.2014].

DIRECTIVE 2003/4/EC OF THE EUROPEAN PARLIAMENT AND OF THE COUNCIL of January 2003 on public access to environmental information and repealing Council Directive 90/313/EEC [2003] OJL 41/26. Online: http://eur-lex.europa.eu/lexUriServ/LexUriServ.do?uri1/40J:L:2003:041:0026:0032:EN:PDF [Accessed 23.09.2014].

EEG (Gesetz für den Ausbau erneuerbarer Energien) [Renewable Energies Act] (2014). Online: http://www.gesetze-im-internet.de/bundesrecht/eeg_2014/gesamt.pdf [Accessed 23.09.2014].

EnLAG (Gesetz zum Ausbau von Energieleitungen) [Power Grid Expansion Act] (2009). Revised 2013. Online: http://www.gesetze-im-internet.de/bundesrecht/enlag/gesamt.pdf [Accessed 23.09.2014].

EnWG (Gesetz über die Elektrizitäts- und Gasversorgung) [Energy Industry Act] (2005). Revised 2014. Online: http://www.gesetze-im-internet.de/bundesrecht/enwg_2005/gesamt.pdf [Accessed 23.09.2014].

Findlay, S. C. (2010): The CEAA Registry as a tool for evaluating CEAA effectiveness. Workshop Presentation. [cited 17 July 2012] Available from: http://www.oaia.on.ca/documents/2010conf/Findlay\%20CEAA\%20workshop.

Fischer, T. B. (2006): Strategic environmental assessment and transport planning: Towards a generic framework for evaluating practice and developing guidance. Impact Assessment and Project Appraisal 24(3): 183-197.

Fischer, T. B. (2007): Theory and Practice of Strategic Environmental Assessment — Towards a More Systematic Approach. London: Earthscan.

FStrAbG (Gesetz über den Ausbau der Bundesfernstraßen) [Highway Expansion Act] (2005). Revised 2006. Online: http://www.gesetze-im-internet.de/fstrausbaug/ BJNR008730971.html [Accessed 23.09.2014]. 
FStrG (Bundesfernstraßengesetz) [Federal Highway Act] (1953). Revised 2013. Online: http://www.gesetze-im-internet.de/bundesrecht/fstrg/gesamt.pdf [Accessed 23.09.2014].

Gaunthier, M.; Simard, L.; Waaub, J.-P. (2011): Public participation in strategic environmental assessment (SEA): Critical review and the Quebec (Canada) approach. Environmental Impact Assessment Review 32(1): 48-60.

GHK (2010): Collection of information and data to support the Impact Assessment study of the review of the EIA directive. A study for DG Environment. London.

Hanna, K. (2000): The paradox of participation and the hidden role of information - A case study. Journal of the American Planning Association 66(4): 398-410.

Hanna, K.; Noble, B. (2011): The Canadian Environmental Assessment Registry: Promise and Reality. UVPReport 25(4): 222-225.

Hartley, N.; Wood, C. (2005): Public participation in environmental impact assessment-implementing the Aarhus Convention. Environmental Impact Assessment Review 25(4): 319-340.

HmbTG (Hamburgisches Tranzparengesetz) [Transparency Act of Hamburg] (2012). Online: http://www.luewu.de/gvbl/2012/29.pdf [Accessed 23.09.2014].

Hourdequin, M.; Landres, P.; Hanson, M. J.; Craig, D. R. (2012): Ethical implications of democratic theory for U.S. public participation in environmental impact assessment. Environmental Impact Assessment Review 35: 37-44.

IFG (Informationsfreiheitsgesetz) [Freedom of Information Act] (2005). Revised 2013. Online: http://www.gesetze-im-internet.de/bundesrecht/ifg/gesamt.pdf [Accessed 23.09.2014].

Jha-Thakur, U.; Gazzola, P.; Peel, D.; Fischer, T. B.; Kidd, S. (2009): Effectiveness of strategic environmental assessment - The significance of learning. Impact Assessment and Project Appraisal 27(2): 133-144.

King, N.; Rajvanshi, A.; Willoughby, S.; Roberts, R.; Mathur, V. B.; Cadman, M; Chavan, V. (2012): Improving access to biodiversity data for, and from, EIAs - A data publishing framework built to global standards. Impact Assessment and Project Appraisal 30(3): 148-156.

Kramer, H. J.; Legat, R.; Naggy, M.; Mayer, J.; Schleidt, K.; Paneli, M. (2011): Die österreichische Umweltinformationspolitik als Vorreiter der Open Government Data Entwicklungen. Online: http://www. conect.at/uploads/tx_posseminar/CONECT_Legat_UI_Vorreiter_von_OGD_2311 2011.pdf. [Accessed 13.02.2013]

Köppel, J.; Geißler, G.; Helfrich, J.; Reisert, J. (2012): A Snapshot of Germany's EIA Approach in light of the United States Archetype. Journal of Environmental Policy and Management 14(4): 1250022-11250022-21.

Köppel, J.; Peters, W.; Wende, W. (2004): Eingriffsregelung, Umweltverträglichkeit sprüfung, FFH-Verträglichkeitsprüfung. Stuttgart (Hohenheim), Ulmer GmbH \& Co.

Landeszentrale für Politische Bildung (n.d.): Landtagswahl 2011 in Baden-Württemberg. Online: http://www.landtagswahl-bw.de/ [Accessed 22.09.2014].

NABEG (Netzausbaubeschleunigungsgesetz Übertragungsnetz) [Grid Expansion Acceleration Act] (2011). Revised 2012. Online: http://www.gesetze-im-internet.de/bundesrecht/nabeg/gesamt.pdf [Accessed 23.09.2014].

Niedersächsisches Ministerium für Ernährung, Landwirtschaft und Verbraucherschutz [Lower Saxony Ministry of Food, Agriculture and Consumer Protection] (n.d): Raumordnungsverfahren. Online: http://www.ml.niedersachsen.de/portal/live.php? navigation_id $1 \frac{1}{4} 1558 \& a r t i-$ cle_id $1 \frac{1}{4} 4666 \&$ \& psmand $1 / 47$ [Accessed 23.09.2014].

NUVPG (Niedersächsisches Gesetz über die Umweltverträglichkeitsprüfung) [Environmental Impact Assessment Act of Lower Saxony] (2007). Revised 2010. Online: http:// www.nds-voris.de [Accessed 23.09.2013].

Odparlik, L. F.; Köppel, J. (2013): Access to information and the role of environmental assessment registries for public participation. Impact Assessment and Project Appraisal 31(4): 324-331.

Odparlik, L. F.; Köppel, J.; Geißler, G. (2013): The grass is always greener on the other side: Der Zugang zu Umweltprüfungs-Dokumenten in Deutschland im internationalen Vergleich. UVP-Report 26(5): 236243.

Parthasarathy, S. (2010): Breaking the expertise barrier: Understanding activist strategies in science and technology policy domains. Science and Public Policy 37(5): 355-367. 
Rau, I.; Hildebrand, J.; Weingarten, E. (2012): Increasing public acceptance by participation in grid expansion procedures - Opportunities and limits of the legal framework. UVP-Report 26(3\&4): 166-175.

Renewables Grid Initiative (2012): European grid declaration on transparency and public participation. Extension of the European grid declaration on electricity network development and nature conservation in Europe, 2011. Online: http://renewables-grid.eu/ fileadmin/user_upload/Files_RGI/European_Grid_Declaration_2nd_Part.pdf [Accessed 23.09.2014].

ROG (Raumordnungsgesetz) (2008). Revised 2009. Online:http://www.gesetze-im-internet.de/bundesrecht/rog_2008/gesamt.pdf [Accessed 23.09.2014].

RoV (Raumordnungsverordnung) (1990). Revised 2012. Online: http://www.gesetze-im-internet.de/bundesrecht/rov/gesamt.pdf [Accessed 23.09.2014].

Ryan, C. M.; Brody, D. O. B.; Lunde, A. I. (2011): NEPA Documents at the US Forest Service: A Blessing and a Curse? UVP-Report 25(4): 192-197.

Schulze-Wolf, T.; Köhler, S. (2008): Online-Beteiligung für das Raumordnungsverfahren zur Küstenautobahn A22. UVP-Report 22(3): 104-110.

Sinclair, A. J.; Schneider, G.; Mitchell, L. (2012): Environmental impact assessment process substitution: Experiences of public participants. Impact Assessment and Project Appraisal 30(2): 85-93.

Slotterback, C. S. (2009): Scoping implementation in National Environmental Policy Act processes in US transport agencies. Transport Research Part D 14: 83-90.

SRU - German Advisory Council on the Environment (2011): Pathways towards a 100\% renewable electricity system. Special report. Online: http://www.umweltrat.de/Share- dDocs/Downloads/EN/02_Special_Reports/2011_10_Special_Report_Pathways_renewables.html [Accessed 23.09.2014].

UfU - Indipendent Institute for Environmental Issues (n.d.): Umweltinformationsrecht. Online: http://www.umweltinformationsrecht.de/ umweltinformationsrecht.html [Accessed 23.09.2014].

UIG, Umweltinformationsgesetz (2004). Revised 2013. Online: http://www.gesetze-im-internet.de/bundesrecht/uig_2005/gesamt.pdf [Accessed 23.09.2014].

UVPG (Gesetz über die Umweltverträglichkeitsprüfung) (2010). Revised 2013. Online: http://www.gesetze-im-internet.de/bundesrecht/uvpg/gesamt.pdf [Accessed 23.09.2014].

Voell, M. (2004): The Umweltdatenkatalog as a repository for environmental impact studies. In: Minier, P and A Susini (eds.): Proc. 18th Int. Conf. Informatics for Environmental Protection: 549-557. Genève.

VwVfG (Verwaltungsverfahrensgesetz) (2003). Revised 2013. Online: http://www.gesetze-im-internet.de/bundesrecht/vwvfg/gesamt.pdf [Accessed 23.09.2014].

Walker, H.; Sinclair, A. J.; Spaling, H. (2014): Public participation in and learning through SEA in Kenya. Environmental Impact Assessment Review 45: 1-9.

Warner, M. B. (2011): Saying no to noise: Resistance builds to planned flight paths at New Berlin Airport. Spiegel Online International. Online: http://www.spiegel.de/international/germany/a-749894.html [Accessed 22.09.2014].

Wende, W.; Scholles, F.; Hartlik, J. (2012): Twenty-five years of EIA in Germany: Our child has grown up. Journal of Environmental Assessment Policy and Management 14(4): 1250023-1-1250023-15.

Wester, M.; Mörn, C. (2013): Gender and public participation: A study of Swedish public debate on the Nord Stream gas pipeline from a gender perspective. Journal of Environmental Assessment Policy and Management 15(03): 1350016-1-20.

Wiklund, H. (2011): Why high participatory ideals fail in practice: A bottom-up approach to public nonparticipation in EIA. Journal of Environmental Assessment Policy and Management 13(2): 159-178.

Wiegert, M. (2009): Tiering and levels of consideration in transport planning - The example of the motorway A 22. UVP-Report 23(1\&2): 88-89.

Wimmer, M. A. (2002): A European perspective towards online one-stop government: The e-GOV project. Electronic Commerce Research and Applications 1: 92-103.

Yin, R. K. (2009): Case Study Research. Design and Methods, 4th Ed. Thousand Oaks, Sage Publisher. 